\title{
Elevated potassium levels suppress T cell activation within tumors
}

\author{
Robert L Eil ${ }^{1 *}$, Rahul Roychoudhuri ${ }^{2}$, David Clever ${ }^{1}$, Shashank Patel ${ }^{1}$, Madhu Sukumar ${ }^{1}$, Jenny H Pan ${ }^{1}$, \\ Douglas Palmer ${ }^{1}$, Christopher A Klebanoff ${ }^{2}$, Nicholas P Restifo ${ }^{1}$
}

From 30th Annual Meeting and Associated Programs of the Society for Immunotherapy of Cancer (SITC 2015) National Harbor, MD, USA. 4-8 November 2015

Tumors progress in immunocompetent hosts despite the ability of the adaptive immune system to recognize cancer cells. Ion gradients regulate $\mathrm{T}$ cell function but their role in intratumoral immune responses is unexplored. We found that the concentration of $\mathrm{K}^{+}$was strikingly elevated within tumors while the concentration of the divalent cations $\mathrm{Ca}^{2+}$ and $\mathrm{Mg}^{2+}$ was similar to serum levels. High $\mathrm{K}^{+}$levels significantly blunted cytokine production and suppression TCR stimulation induced gene transcription in $\mathrm{CD}^{+}{ }^{+}$and $\mathrm{CD} 4^{+}$effector T cells. Moreover, polarization of $\mathrm{CD}^{+}$and $\mathrm{CD} 4^{+} \mathrm{T}$ cells in high $\mathrm{K}^{+}$ suppressed effector differentiation and promoted the formation of $\mathrm{CD} 4^{+} \mathrm{Foxp}^{+} \mathrm{T}_{\text {reg }}$ cells. Surprisingly, this was not due to an attenuation of TCR induced $\mathrm{Ca}^{2+}$ flux, but rather to reduced activation of the serine/ threonine Akt-mTOR pathway and could be partially reversed by overexpression of constitutively active Akt1. This coincided with the finding that okadaic acid, an inhibitor of the serine/threonine phosphatase PP2A, rendered effector cells resistant to the inhibitory effects of high $\mathrm{K}^{+}$ and restored cytokine function within tumors. Additionally, expression of a peptide inhibitor targeting the PP2A complex provided resistance to the inhibitory effect of elevated $\mathrm{K}^{+}$. These findings identify a novel mechanism of ionic regulation of TCR induced signals and immunosuppression within tumors whereby locally high extracellular concentrations of normally intracellular ions suppress immune function to promote tumor growth.

\footnotetext{
Authors' details

${ }^{1} \mathrm{NIH} / \mathrm{NCl}$ - Surgery Branch, Bethesda, MD, USA. ${ }^{2}$ Center for Cancer Research, $\mathrm{NCI} / \mathrm{NIH}$, Bethesda, MD, USA.
}

Published: 4 November 2015

${ }^{1} \mathrm{NHH} / \mathrm{NCl}$ - Surgery Branch, Bethesda, MD, USA

Full list of author information is available at the end of the article
doi:10.1186/2051-1426-3-S2-P403

Cite this article as: Eil et al.: Elevated potassium levels suppress $\mathrm{T}$ cell activation within tumors. Journal for ImmunoTherapy of Cancer 2015 3(Suppl 2):P403.
Submit your next manuscript to BioMed Central and take full advantage of:

- Convenient online submission

- Thorough peer review

- No space constraints or color figure charges

- Immediate publication on acceptance

- Inclusion in PubMed, CAS, Scopus and Google Scholar

- Research which is freely available for redistribution

Submit your manuscript at www.biomedcentral.com/submit
C Biomed Central 